\title{
HUBUNGAN ANTARA KONSENTRASI KLOROFIL-A DENGAN TINGKAT PRODUKTIVITAS PRIMER MENGGUNAKAN CITRA SATELIT LANDSAT-8
}

\section{RELATIONSHIP BETWEEN CHLOROPHYLL-A CONCENTRATION WITH PRIMARY PRODUCTIVITY RATE USING LANDSAT 8 IMAGERY}

\author{
Mulkan Nuzapril ${ }^{1}$, Setyo Budi Susilo², James P. Panjaitan ${ }^{2}$ \\ ${ }^{1}$ Program Studi Teknologi Kelautan, Sekolah Pascasarjana \\ ${ }^{2}$ Departemen Ilmu dan Teknologi Kelautan, \\ Fakultas Perikanan dan Ilmu Kelautan, Institut Pertanian Bogor \\ Korespondensi : mnuzapril@gmail.com
}

\begin{abstract}
Chlorophyll-a is a phytoplankton pigment involved in photosynthesis. Chlorophyll-a concentration detection through satellite orbiting can only be infered the concentration of chlorophyll-a at sea surface and could not estimate the sea primary productivity. Sea Primary productivity may last up to a depth of compensation or the depth at which the intensity of light stayed at least $1 \%$ of sea surface light intensity. However, the aim of this study is to find out the relationships between the concentration of chlorophyll-a and primary productivity so that the concentration of chlorophyll-a could be used to predict primary productivity. The linear regression equation have been applied to construct model explaing relationship between the chlorophyll-a concentration and sea primary productivity. The equation explaing on chlorophyll-a concentrations with primary productivity is $\mathrm{PP}=22.746+95.536 \mathrm{Keu}\left(\mathrm{R}^{2}\right)=0.66$ where PP is the sea primary productivity, Keu is the average of chlorophyll-a concentration throughout the water column. The results of these equations can be applied to satellite imagery so that it can assist in monitoring water quality conditions.
\end{abstract}

Keyword: Chlorophyll-a concentration, light intensity, primary productivity, satellite imagery

\begin{abstract}
ABSTRAK
Klorofil-a merupakan pigmen fitoplankton yang berperan dalam proses fotosintesis. Deteksi konsentrasi klorofil-a melalui satelit hanya dapat menduga konsentrasi klorofil-a permukaan dan bukan produktivitas primer. Produktivitas primer dapat berlangsung sampai kedalaman kompensasi atau kedalaman dimana intensitas cahaya tinggal 1\% dari intensitas cahaya permukaan. Penelitian ini bertujuan untuk mencari hubungan antara konsentrasi klorofil-a dengan produktivitas primer sehingga konsentrasi klorofil-a dapat digunakan untuk menduga produktivitas primer. Analisis regresi linier dilakukan terhadap model hubungan antara konsentrasi klorofil-a dengan produktivitas primer. Persamaan hubugan antara konsentrasi klorofil dengan produktivitas primer adalah $\mathrm{PP}=22.746+95.536 \mathrm{Keu}$ dengan $\left(\mathrm{R}^{2}\right)=$ 0.66 dimana PP adalah produktivitas primer dan Keu adalah konsentrasi klorofil-a rata-rata di seluruh kolom perairan. Hasil persamaan tersebut dapat diaplikasikan untuk citra satelit sehingga dapat membantu dalam memonitoring kondisi kualitas perairan.
\end{abstract}

Kata kunci: Konsentrasi klorofil-a, intensitas cahaya, produktivitas primer, citra satelit 


\section{PENDAHULUAN}

Klorofil-a merupakan indikator kelimpahan fitoplankton di perairan yang berperan dalam proses fotosintesis (Zhang \& Han 2015; Moses et al. 2009). Fitoplankton berkontribusi secara besar untuk mengetahui produktivitas primer di perairan. Produksi karbon organik selama proses fotosintesis didefinisikan sebagai produktivitas primer atau produktivitas primer bersih (Net Primary Productivity) (Lee et al. 2014). Produktivitas primer bersih merupakan kunci pengukuran kesehatan lingkungan dan pengelolaan sumberdaya laut (Behrenfald et al. 2005).

Pengukuran produktivitas primer secara konvensional untuk cakupan wilayah yang besar membutuhkan waktu dan biaya yang sangat mahal. Satelit secara rutin telah menyediakan beberapa variabel biofisik seperti variabel konsentrasi klorofil-a dan suhu permukaan laut. Data yang telah didapat oleh sensor satelit, dapat digunakan untuk membuat model estimasi produktivitas primer, sehingga estimasi produktivitas primer lebih cepat dan efisien (Ma et al. 2014). Salah satu kendala membuat model produktivitas primer menggunakan penginderaan jauh adalah bahwa sensor satelit hanya dapat mendeteksi konsentrasi klorofil-a permukaan dan bukan produktivitas primer (Susilo 1999).

Model skala global untuk menduga produktivitas primer melalui citra satelit telah dikembangkan yaitu model Vertically Generelized Production Model (VGPM) (Behrenfald \& Falkowski 1997) dan Carbon based Production Model (CbPM) (Behrenfald et al. 2005). Model tersebut kurang akurat untuk wilayah yang kecil contohnya daerah pesisir, karena memiliki resolusi spasial yang rendah. Oleh sebab itu dengan menggunakan citra satelit landsat 8 OLI dapat diadaptasi untuk pemetaan sebaran produktivitas primer karena mempunyai resolusi spasial yang tinggi (Zhang \& Han 2015). Penelitian mengenai hubungan antara konsentrasi klorofil-a dan produktivitas primer untuk aplikasi teknologi penginderaan jauh telah dilakukan oleh Susilo et al. (1995) di perairan Subang dan Susilo (1999) di perairan pantai selatan Jawa Barat.

Pengembangan algoritma khususnya di Indonesia dalam mengestimasi produktivitas primer melalui pengukuran satelit masih harus banyak dilakukan. Pendugaan nilai produktivitas primer dapat dicari menggunakan informasi nilai konsentrasi klorofil-a. Namun, pengukuran satelit hanya mampu mendeteksi kedalaman permukaan, sedangkan produktivitas primer berlangsung sampai kedalaman kompensasi. Berdasarkan permasalahan tersebut, diperlukan suatu kajian hubungan antara nilai konsentrasi klorofil-a seluruh daerah eufotik dengan produktivitas primer untuk mendapatkan hasil yang lebih akurat. Penelitian ini bertujuan untuk menganalisis konsentrasi klorofil-a sampai kedalaman kompensasi dan menganalisis produktivitas primer berdasarkan nilai konsentrasi klorofil-a sehingga dapat diaplikasikan untuk citra satelit landsat 8-OLI.

\section{METODE PENELITIAN}

Penelitian dilaksanakan pada tanggal 15-18 Mei 2016 di perairan kepulauan Karimun Jawa (Gambar 1). Karimun Jawa terletak di laut Jawa tepatnya berada di sebelah utara Kabupaten Jepara, Jawa Tengah. Secara geografis lokasi penelitian terletak pada koordinat 50 45' 30" LS - 50 54' 30" LS dan 1100 23'30" BT - 1100 31'30" BT. Adapun lokasi penelitian dilakukan di 20 stasiun pengamatan yang ditentukan secara acak dengan menyebar disekeliling pulau Karimun Jawa dan Kemujan.

Pengambilan sampel air dilakukan di setiap stasiun pengamatan pada tiga kedalaman yang berbeda. Sampel air yang diambil yaitu pada kedalaman permukaan, kolom perairan dan kedalaman kompensasi menggunakan van dorn bottle sampler. Penentuan tiga kedalaman tersebut dihitung berdasarkan pola intensitas cahaya yang diukur pada kedalaman $0 \mathrm{~m}, 5 \mathrm{~m}$ dan $7 \mathrm{~m}$ untuk mencari nilai koefisien atenuasi (k) menggunakan luxmeter underwater datalogger 2000 menggunakan hukum Beer Lambert (Parson et al. 1984).

$$
I z=I o e^{-k z}
$$

Iz adalah intensitas cahaya pada kedalaman $z$ (lux), Io adalah intensitas cahaya permukaan (lux), $\mathrm{k}$ adalah koefisien atenuasi (m-1) dan $z$ kedalaman (m). 


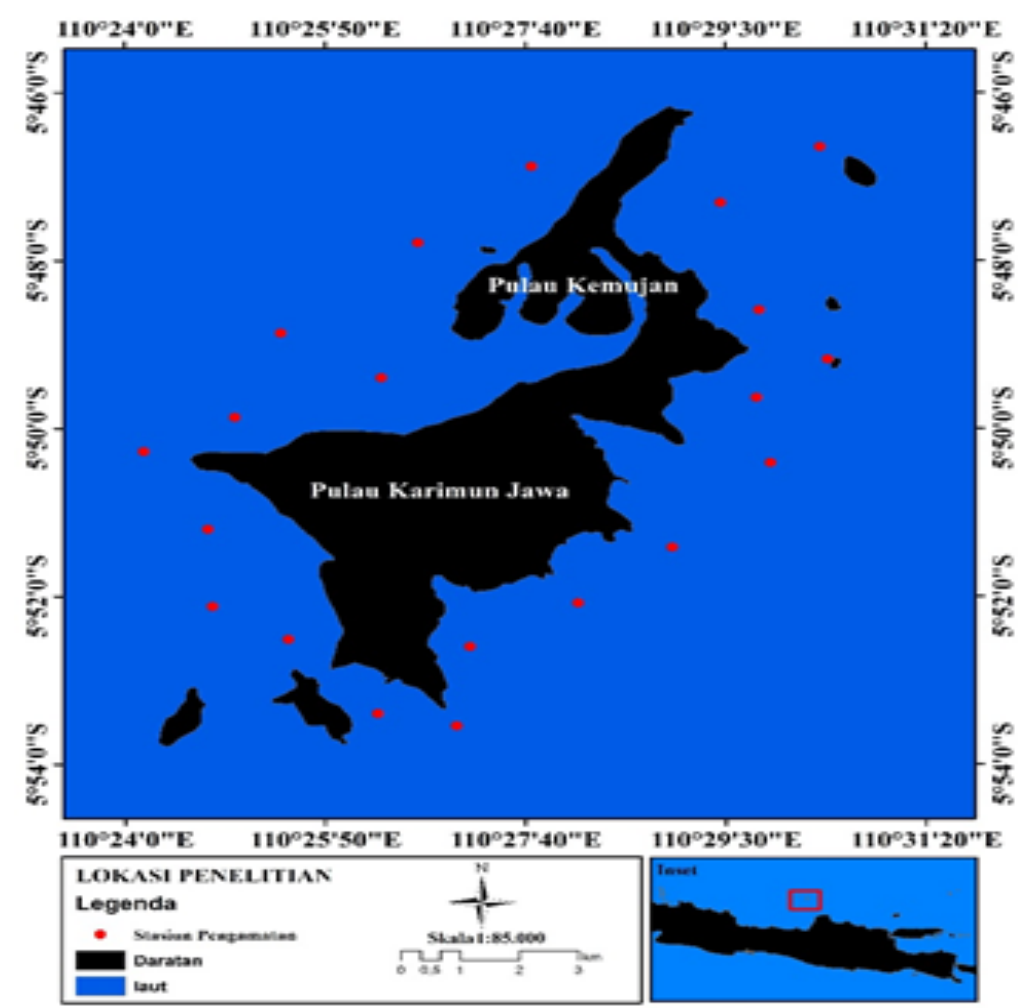

Gambar 1. Peta lokasi penelitian, Kepulauan Karimun Jawa

\section{Pengambilan data}

Sampel air diambil menggunakan van dorn bottle sampler kemudian disaring menggunakan kertas saring berukuran pori $0.45 \mu \mathrm{m}$ dan menggunakan alat saring (hand vacum pump). Hasil penyaringan kemudian disimpan dalam wadah bersuhu $4{ }^{\circ} \mathrm{C}$ dan terhindar dari sinar cahaya. Hasil penyaringan kemudian dianalisis di laboratorium Pengelolaan Sumberdaya Ikan dan Lingkungan, Universitas Diponegoro, Semarang. Sampel dihancurkan menggunakan tissue grinder dan diberi larutan aseton 90\% untuk melarutkan pigmen klorofil-a. Pigmen yang telah diekstrak kemudian diletakkan pada kuvet dan ditambahkan $0.1 \mathrm{ml} \mathrm{N}$ HCL. Setelah itu diukur dengan menggunakan spektrofotometer pada panjang gelombang $630 \mathrm{~nm}, 647 \mathrm{~nm}, 664 \mathrm{~nm}$ dan $750 \mathrm{~nm}$. Untuk mendapatkan nilai konsentrasi klorofil-a dihitung menggunakan rumus (APHA 2012).

$$
C h l-a=\frac{C a x V a}{V x d}
$$

Chl-a adalah konsentrasi klorofil-a $\left(\mathrm{mg} / \mathrm{m}^{3}\right), \quad \mathrm{Ca}$ adalah perhitungan nilai absorbansi (11.85 x E664) - (1.54 x E647) (0.08 $\times$ E630), Va adalah volume aseton (ml), $V$ adalah volume sampel air yang disaring (L) $d$ adalah diameter cuvet dan E merupakan absorbansi pada panjang gelombang yang berbeda (yang dikoreksi dengan panjang gelombang $750 \mathrm{~nm}$ ). Data konsentrasi klorofil-a untuk setiap stasiun kemudian dibuat rata-rata secara vertikal. Hubungan antara konsentrasi klorofil-a permukaan dengan rata-rata konsentrasi klorofil-a setiap stasiun di analisis menggunakan regresi linier sederhana. Rata-rata konsentrasi klorofil-a dapat disebut juga konsentrasi klorofil-a kolom air seluruh daerah eufotik.

Pengukuran produktivitas primer dilakukan secara insitu dengan menggunakan metode botol terang dan botol gelap. Pengukuran dilakukan secara komposit dari sampel air yang telah didapat dari tiga lapisan kedalaman. Botol tersebut kemudian diinkubasi selama 3-5 jam pada siang hari antara pukul 10.00-15.00 WIB. Sebelum menghitung nilai oksigen terlarut pada botol yang telah diinkubasi, dilakukan pengukuran pada botol awal atau botol initial. Oksigen terlarut yang diukur menggunakan metode Winkler (APHA 2012). Nilai oksigen terlarut pada botol terang dan gelap digunakan untuk menghitung nilai produktivitas primer bersih (Net Primary Productivity) dan produktivitas kotor (Gross Primary Productivity). Namun, karena produktivitas primer bersih merupakan nilai produksi karbon oleh fitoplankton setelah 
dikurangi dengan proses respirasi, sehingga data produktivitas primer bersih yang digunakan dalam analisis. Adapun rumus yang digunakan untuk menghitung nilai produktivitas primer bersih (NPP) adalah:

$$
N P P=\frac{\left(\mathrm{O}_{2} B T\right)-\left(\mathrm{O}_{2} B A\right) \times 1000 \times 0.375}{P Q(t)}
$$

NPP adalah produktivitas primer bersih (mgC $\left./ \mathrm{m}^{3} / \mathrm{jam}\right), O_{2} B T$ adalah oksigen pada botol terang setalah diinkubasi (mg/1), $\mathrm{O}_{2} B A$ oksigen pada inisial sebelum diinkubasi (mg/1), PQ adalah Photosyntetic Quotien = 1.2, $t$ adalah waktu inkubasi (jam), 1000 merupakan konversi liter menjadi $\mathrm{m}^{3}$ dan 0.375 merupakan konversi oksigen menjadi karbon. Data produktivitas primer bersih dan konsentarasi klorofil-a kolom perairan yang telah dihitung kemudian dianalisis menggunakan persamaan regresi linier sederhana untuk mendapatkan hubungan antara konsentrasi klorofil-a kolom air seluruh daerah eufotik dengan produktivitas primer. Model hubungan ini dirancang agar konsentrasi klorofil-a dapat digunakan untuk menduga produktivitas primer.

\section{Pengolahan citra satelit}

Data citra satelit yang digunakan adalah Landsat 8 OLI pada path/row 120/64 dengan tanggal perekaman satelit 15 Mei 2016. Tahap pengolahan citra satelit dimulai dengan melakukan koreksi geometrik dan radiometrik. Koreksi geometrik pada prinsipnya digunakan untuk memperbaiki kesalahan posisi citra satelit terhadap lokasi sebenarnya di permukaan bumi dan memiliki acuan sistem koordinat. Proses pengolahan data citra satelit Landsat-8 OLI juga dengan melakukan koreksi radiometrik untuk mengubah nilai digital number (DN) menjadi nilai reflektansi dengan resolusi radiometrik 16-bit integer pada produk level 1 sehingga dikonversi menjadi nilai reflektansi Top of Atmosphere (TOA). Konversi nilai untuk reflektansi TOA menggunakan persamaan dari USGS (2015):

$$
p \lambda^{\prime}=\operatorname{Mp} x Q \operatorname{cal} x A p
$$

$\rho \lambda^{\prime}$ adalah reflektansi TOA (top of atmosfer) tanpa koreksi sudut matahari, Mp adalah REFLECTANCEW_MULT_BAND_x (berasal dari metadata) dimana $\mathrm{x}$ adalah nomor band, Ap adalah REFLECTANCEW_ ADD_BAND_x (berasal dari metadata) dimana x adalah nomor band, Qcal adalah nilai DN. Reflektansi TOA yang telah dikoreksi sudut elevasi matahari dihitung menggunakan persamaan:

$$
\rho \lambda^{\prime}=\frac{p \lambda^{\prime}}{\sin \theta}
$$

$\rho \lambda$ adalah TOA reflektansi yang sudah terkoreksi sudut elevasi matahari dan $\sin (\theta)$ adalah sudut elevasi matahari. Ekstraksi nilai konsentrasi klorofil-a menggunakan algoritma yang dikembangkan oleh Pentury (1997), yang disesuaikan dengan nilai konsentrasi klorofil-a insitu dan menggunakan nilai reflektansi Landsat 8 daerah penelitian, sehingga persamaan yang dihasilkan adalah sebagai berikut:

$$
\text { Chl }-a=0.067 \frac{\lambda h i j a u}{\lambda b i r u}+0.126
$$

Chl-a adalah konsentrasi klorofil-a citra satelit $\left(\mathrm{mg} / \mathrm{m}^{3}\right), \lambda$ hijau adalah nilai reflektansi pada panjang gelombang hijau dan $\lambda$ biru adalah nilai reflektansi pada panjang gelombang biru.

\section{Akurasi data}

Pengujian akurasi data dilakukan untuk mengetahui akurasi dari pengukuran dengan cara membandingkan data antara hasil estimasi citra satelit dengan data pengukuran insitu menggunakan analisis Root Mean Square Eror (RMSE). Perhitungan RMSE adalah sebagai berikut:

$$
R M S E=\sqrt{\frac{\sum_{i=1}^{n}(z i-z j)^{2}}{n}}
$$

$Z i$ adalah data estimasi citra satelit, $Z j$ adalah data pengukuran insitu, $n$ adalah jumlah data. Apabila nilai RMSE $<0.3$ mengindikasikan keakuratan pada model dan nilai pengukuran insitu (Hill \& Zimmerman 2010). Analisis kesesuaian RMSE merupakan indikator kesalahan yang didasarkan pada total kuadratis dari persimpangan antara hasil model dengan hasil observasi. Pengukuran menggunakan model dapat diprediksi tingkat eror atau kesalahan dengan menggunakan RMSE. 


\section{HASIL DAN PEMBAHASAN}

\section{Koefisien atenuasi}

Berdasarkan hasil perhitungan koefisien atenuasi menggunakan hukum Beer Lambert didapatkan nilai kisaran koefisien atenuasi antara $0.137-0.211$ $\mathrm{m}^{-1}$ (Gambar 2b). Pola distribusi vertikal intensitas cahaya memperlihatkan penurunan secara eksponensial dengan bertambahnya kedalaman (Gambar 2a). Penurunan intensitas cahaya ini dipengaruhi oleh besar kecilnya nilai koefisien atenuasi. Pendugaan besarnya intensitas cahaya yang masuk ke kolom perairan memperlihatkan pola distribusi vertikal cahaya di perairan, dimana semakin dalam cahaya menembus lapisan air maka nilai intensitasnya akan semakin berkurang.

Berdasarkan pola intensitas cahaya pada Gambar 2a diperoleh rata-rata nilai koefisien atenuasi yaitu $0.165 \mathrm{~m}^{-1}$ sehingga kolom air permukaan atau kedalaman permukaan sekitar 0 - $12 \mathrm{~m}$. Dari persamaan tersebut juga kemudian dapat diduga ratarata kedalaman kompensasi yaitu pada kedalaman 28 - $30 \mathrm{~m}$. Pola intensitas cahaya tersebut digunakan untuk menentukan lapisan kedalaman suatu perairan yang masih ditembus cahaya karena faktor terpenting dalam proses fotosintesis merupakan energi cahaya. Menurut Kirk (2011) respon fotosintesis di perairan terhadap intensitas cahaya yang berbeda akan mempengaruhi kualitas spektral yang kemudian berpengaruh terhadap parameter lingkungan sebagai faktor pembatas fotosintesis.

\section{Hubungan konsentrasi klorofil-a permukaan dengan konsentrasi klorofil-a kolom air}

Konsentrasi klorofil-a permukaan memiliki nilai berkisar antara $0.118-0.509$ $\mathrm{mg} / \mathrm{m}^{3}$ dengan nilai rata-rata $0.233 \mathrm{mg} /$ $\mathrm{m}^{3}$. Rata-rata sebaran nilai konsentrasi klorofil-a di tiap stasiun dari kedalaman permukaan sampai kedalaman kompensasi berkisar antara $0.114-0.482 \mathrm{mg} / \mathrm{m}^{3}$ dengan nilai rata-rata $0.288 \mathrm{mg} / \mathrm{m}^{3}$. Rata-rata konsentrasi klorofil-a seluruh kedalaman pada zona eufotik dapat disebut juga konsentrasi klorofil-a kolom air seluruh daerah eufotik. Berdasarkan hasil tersebut kemudian dapat dihitung hubungan antara konsentrasi klorofil-a permukaan dengan konsentrasi klorofil-a kolom air seluruh daerah eufotik yang ditunjukkan pada Gambar 3.

Hasil analisis regresi linier antara konsentrasi klorofil-a permukaan dengan konsentrasi klorofil-a kolom air seluruh daerah eufotik menghasilkan persamaan $\mathrm{Keu}=0.1442+0.615 \mathrm{C}$, dimana Keu adalah konsentrasi klorofil-a kolom air seluruh daerah eufotik dan $\mathrm{C}$ adalah konsentrasi klorofil-a permukaan. Berdasarkan nilai koefisien korelasi menunjukkan bahwa nilai konsentrasi klorofil-a permukaan memiliki korelasi yang kuat terhadap nilai konsentrasi klorofil-a kolom air seluruh daerah eufotik dengan korelasi sebesar 0.75. Namun, pengaruh konsentrasi klorofil-a permukaan terhadap konsentrasi klorofil-a kolom air seluruh daerah eufotik tidak cukup kuat dengan koefisien determinasi 0.56. Oleh sebab itu konsentrasi klorofil-a permukaan tidak dapat menggambarkan keseluruhan produktivitas primer. Menurut Campbell et al. (2002) konsentrasi klorofil-a permukaan hanya mampu menjelaskan kurang lebih 30 $\%$ produktivitas primer laut.

Sebaran spasial konsentrasi klorofil-a permukaan data insitu menunjukkan konsentrasi klorofil-a lebih tinggi di sekitar pulau Menjangan Kecil dan Menjangan Besar (Gambar 4). Hasil analisis citra satelit konsentrasi klorofil-a di perairan pulau Karimun Jawa dan Kemujan berkisar antara 0.1-0.6 mg/m $\mathrm{m}^{3}$ (Gambar 5). Konsentrasi klorofil-a di perairan Indonesia rata-rata yaitu $0.19 \mathrm{mg} / \mathrm{m}^{3}$ (Nontji 1984). Nilai eror atau RMSE antara nilai pengukuran insitu dan analisis citra satelit sebesar 0.06. Hasil tersebut menggambarkan keakuratan model deteksi citra satelit dengan pengukuran insitu karena nilai eror masih $<0.3$.

Sebaran konsentrasi klorofil-a lebih tinggi berada di perairan pantai dibandingkan laut lepas karena tingginya suplai nutrien yang berasal dari daratan. Pemantauan kualitas perairan secara konvensional terbatas secara spasial dan temporal. Teknik penginderaan jauh dapat digunakan untuk memonitoring kualitas perairan baik secara spasial maupun temporal. Analisis citra satelit juga dapat mengindentifikasi eutrofikasi menggunakan pengamatan multitemporal melalui penginderaan jauh (Moses et al. 2009). 


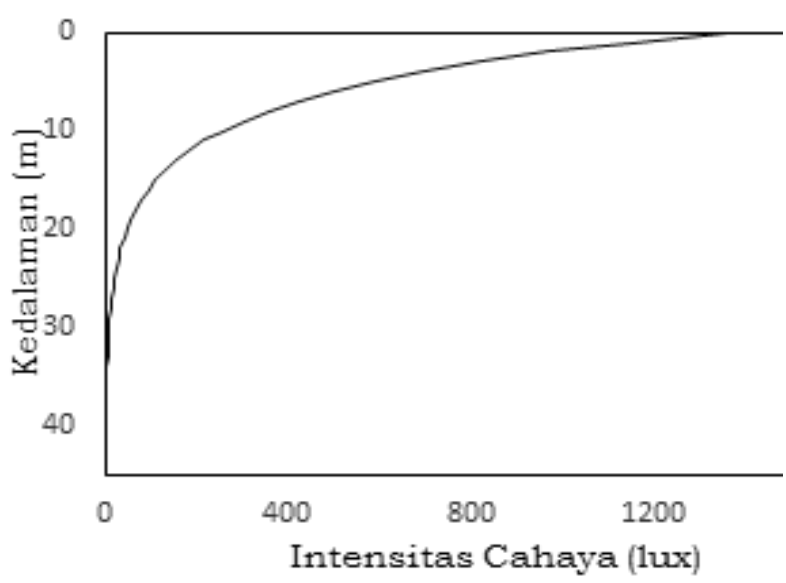

(a)

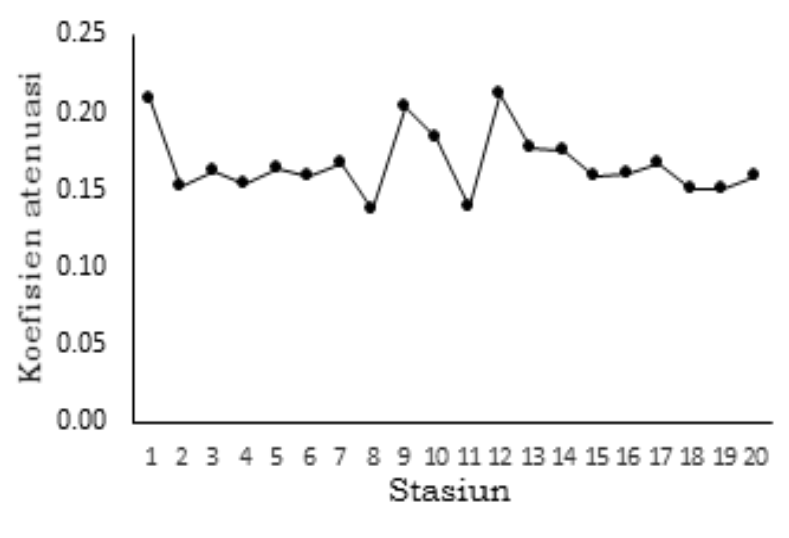

(b)

Gambar 2. (a) Pola intensitas cahaya (b) Nilai koefisien atenuasi di setiap stasiun

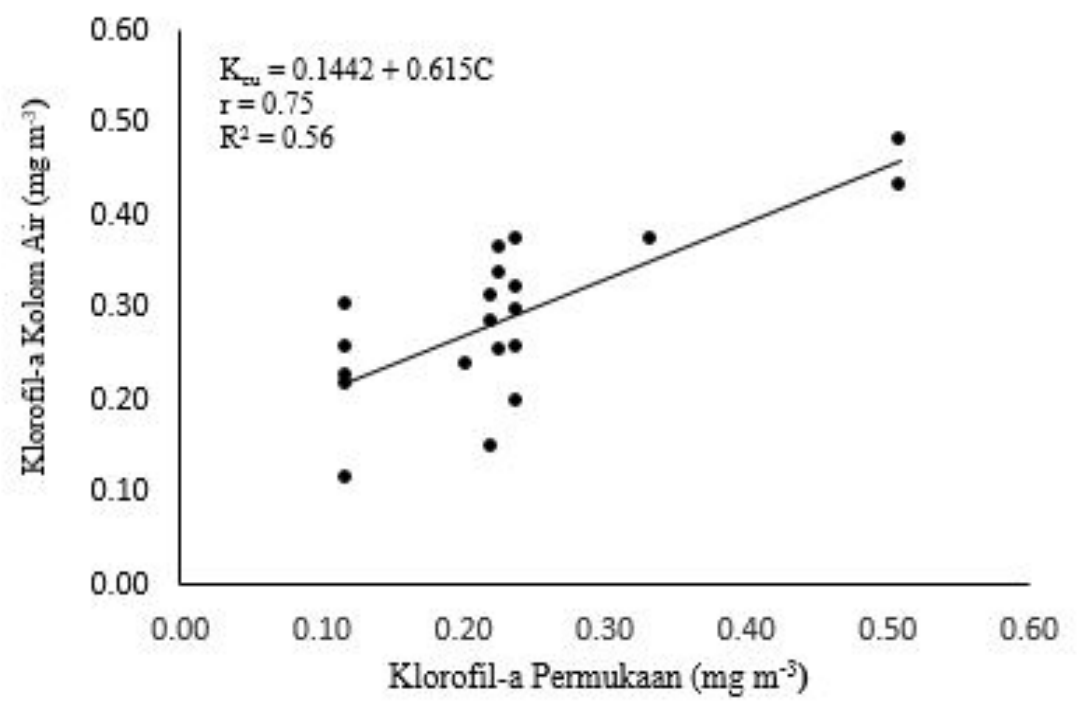

Gambar 3. Model regresi antara konsentrasi klorofil-a permukaan dengan konsentrasi klorofil-a kolom air seluruh daerah eufotik

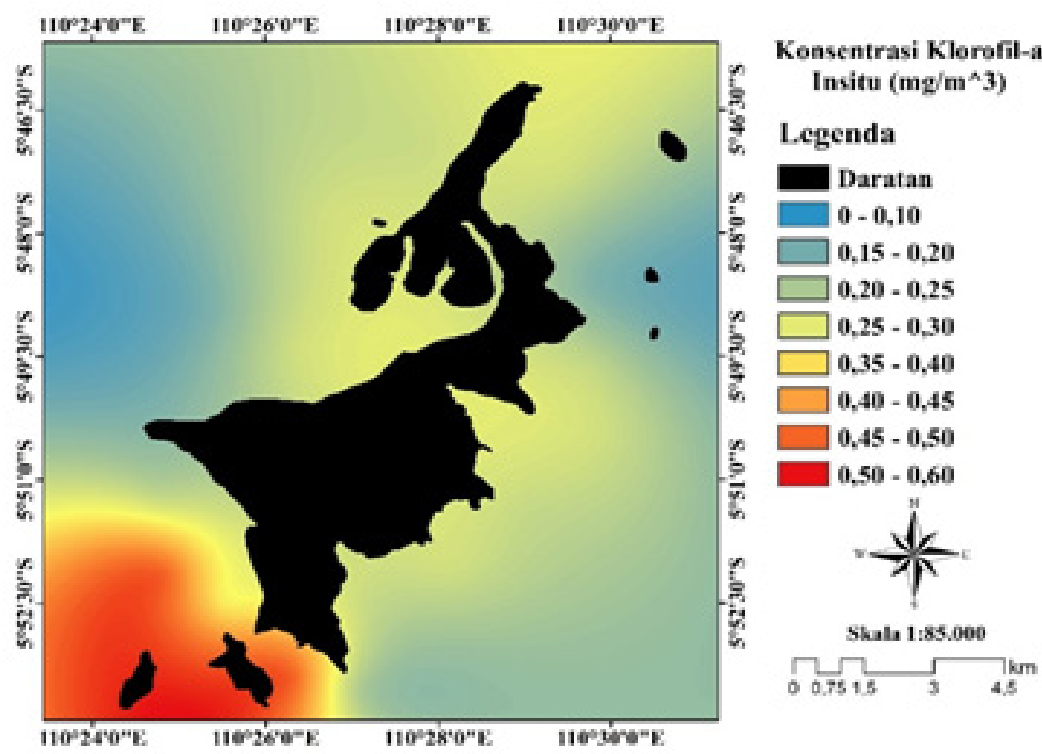

Gambar 4. Peta sebaran spasial konsentrasi klorofil-a data insitu 


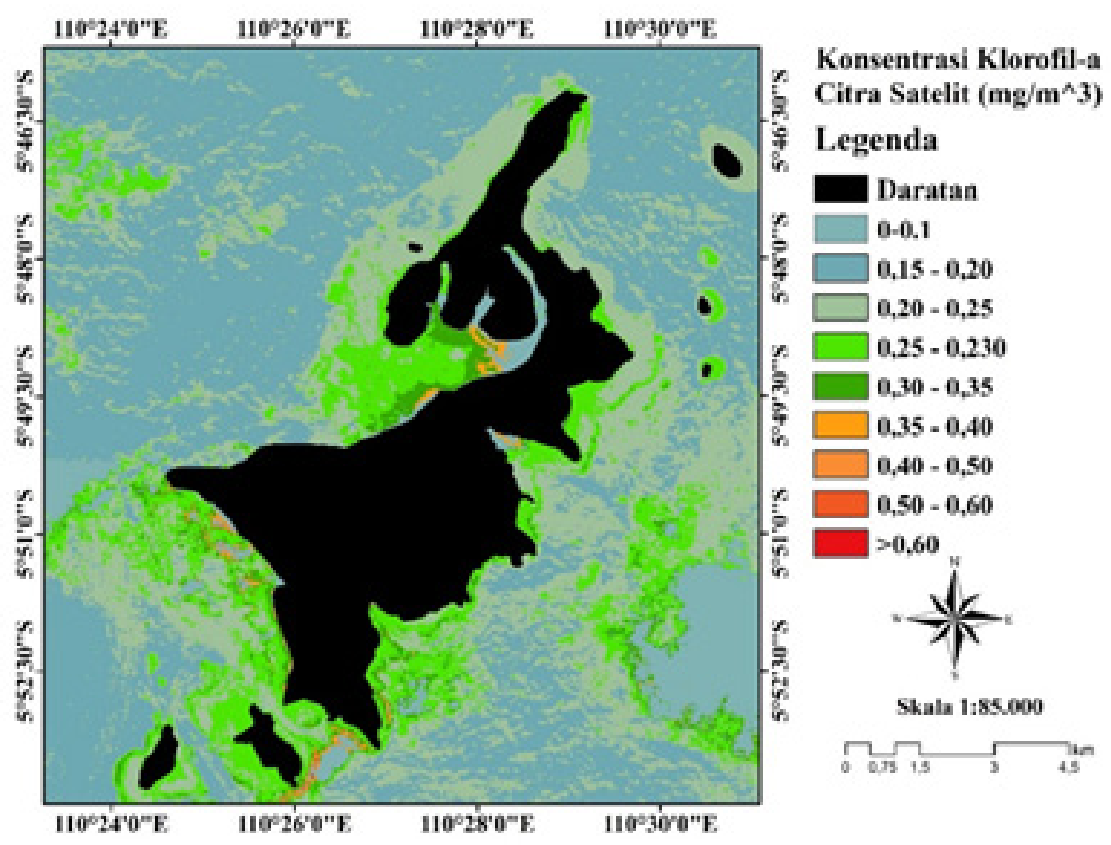

Gambar 5. Peta Sebaran spasial konsentrasi klorofil-a citra satelit

\section{Hubungan konsentrasi klorofil-a kolom air dengan produktivitas primer}

Nilai produktivitas primer berdasarkan pengukuran insitu berkisar antara 37.5$75 \mathrm{mgC} / \mathrm{m}^{3} / \mathrm{jam}$. Hasil nilai pengukuran produktivitas primer tersebut tidak jauh berbeda dengan pengukuran produktivitas primer yang dilakukan Tambaru (2000) di perairan teluk Hurun yaitu antara 36-53 $\mathrm{mgC} / \mathrm{m}^{3} /$ jam dan Tambaru (2008) di perairan Maros yaitu berkisar $12.44-58.04 \mathrm{mgC} / \mathrm{m}^{3}$ / jam. Hasil pengukuran produktivitas primer insitu dengan nilai konsentrasi klorofil-a kolom air seluruh daerah eufotik dianalisis menggunakan analisis regresi linier (Gambar 6) sehingga konsentrasi klorofil-a dapat digunakan untuk mengestimasi nilai produktivitas primer.

Berdasarkan hasil pengukuran produktivitas primer bersih, dapat diestimasi produksi karbon bersih harian pada wilayah penelitian sebesar $502 \mathrm{mgC} /$ $\mathrm{m}^{3}$ /hari dan nilai produktivitas tahunan sebesar $183 \mathrm{gC} / \mathrm{m}^{3} /$ tahun. Hasil tersebut dapat menggambarkan nilai karbon yang dihasilkan pada proses fotosintesis sehingga dapat dilakukan pengamatan produktivitas primer perairan secara berkala. Secara umum nilai NPP di perairan laut $>274 \mathrm{mgC} /$ $\mathrm{m}^{2}$ /hari (Behrenfald \& Falkowski 1997) dan perairan laut lepas sekitar $50 \mathrm{gC} / \mathrm{m}^{2} /$ tahun Supriharyono (2009).

Hubungan antara produktivitas primer dengan konsentrasi klorofil-a rata-rata menghasilkan persamaan: $\mathrm{PP}=22.746+$
95.536Keu, dimana PP adalah produktifitas primer dan $\mathrm{K}$ adalah konsentrasi klorofil-a kolom air seluruh daerah eufotik dengan nilai korelasi sebesar 0.81 dan koefisen determinasi sebesar 0.66. Penelitian mengenai hubungan antara konsentrasi klorofil-a dengan produktivitas primer yang dilakukan Susilo (1999) menunjukkan nilai koefisien korelasi sebesar 0.67. Nilai korelasi yang didapatkan lebih rendah dibandingkan dengan hasil pengukuran. Hal tersebut karena pengukuran di selatan Jawa Barat hanya di ukur sampai kedalaman $10 \mathrm{~m}$ dan mempunyai karakteristik perairan yang berbeda. Menurut (Siswanto et al. 2005) profil vertikal klorofil-a secara umum tidak hanya untuk mengestimasi biomassa total fitoplankton tetapi juga sebagai salah satu prinsip untuk menganalisis model estimasi produktivitas primer dengan menggunakan penginderaan jauh satelit.

Sebaran nilai produktivitas insitu menunjukkan produktivitas primer lebih tinggi di perairan yang dekat dengan daratan dan semakin rendah ke arah lepas pantai (Gambar 7). Analisis citra satelit pada Gambar 8 juga menunjukkan di perairan di sekitar pesisir lebih tinggi dibandingkan perairan yang menjauhi daratan atau di sekitar lepas pantai. Salah satu sebab produktivitas primer di sekitar daratan lebih tinggi dikarenakan pada perairan pantai terdapat ekosistem penting seperti ekosistem karang, lamun dan mangrove yang menyuplai nutrien. Umumnya produktivitas primer yang tinggi terdapat pada perairan 
pantai yang mempunyai kedalaman perairan dangkal yang menerima cahaya matahari dan sejumlah nutrien dari daratan (Asriyana \& Yuliana 2012). Perbandingan nilai pengukuran insitu dengan analisis citra satelit ditunjukkan pada Gambar 9.

Selisih antara nilai pengukuran produktivitas primer citra satelit dengan pengukuran insitu (-) $12.66-10.57 \mathrm{mgC} / \mathrm{m}^{3} /$ jam dengan akurasi sebesar $72.87 \%$. Nilai akurasi tersebut menggambarkan akurasi yang tinggi antara pengukuran insitu dengan citra satelit. Keakuratan pengukuran produktivitas primer menggunakan analisis citra satelit berfungsi untuk membantu mengestimasi produktivitas primer dengan wilayah yang luas. Selain itu, analisis citra satelit dapat digunakan untuk memonitoring produktivitas primer secara temporal. Pengetahuan pada variabilitas spasiotemporal dalam produktivitas primer sangat penting untuk memprediksi dampak dan respon pada ekosistem perairan khususnya pesisir (Hirawake et al. 2012).

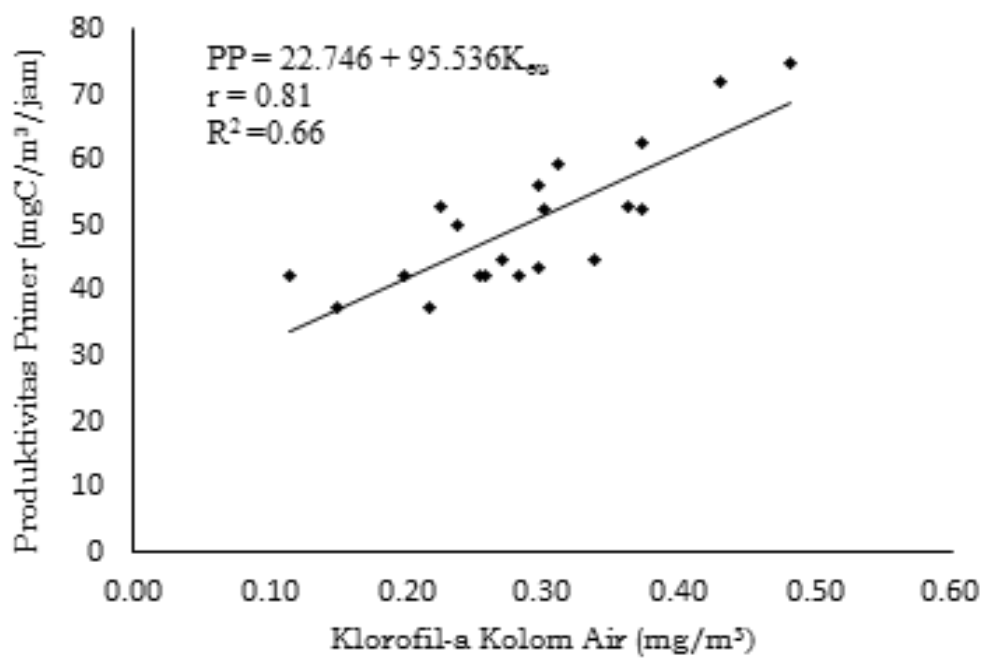

Gambar 6. Hubungan antara konsentrasi klorofil-a kolom air dengan produktivitas primer

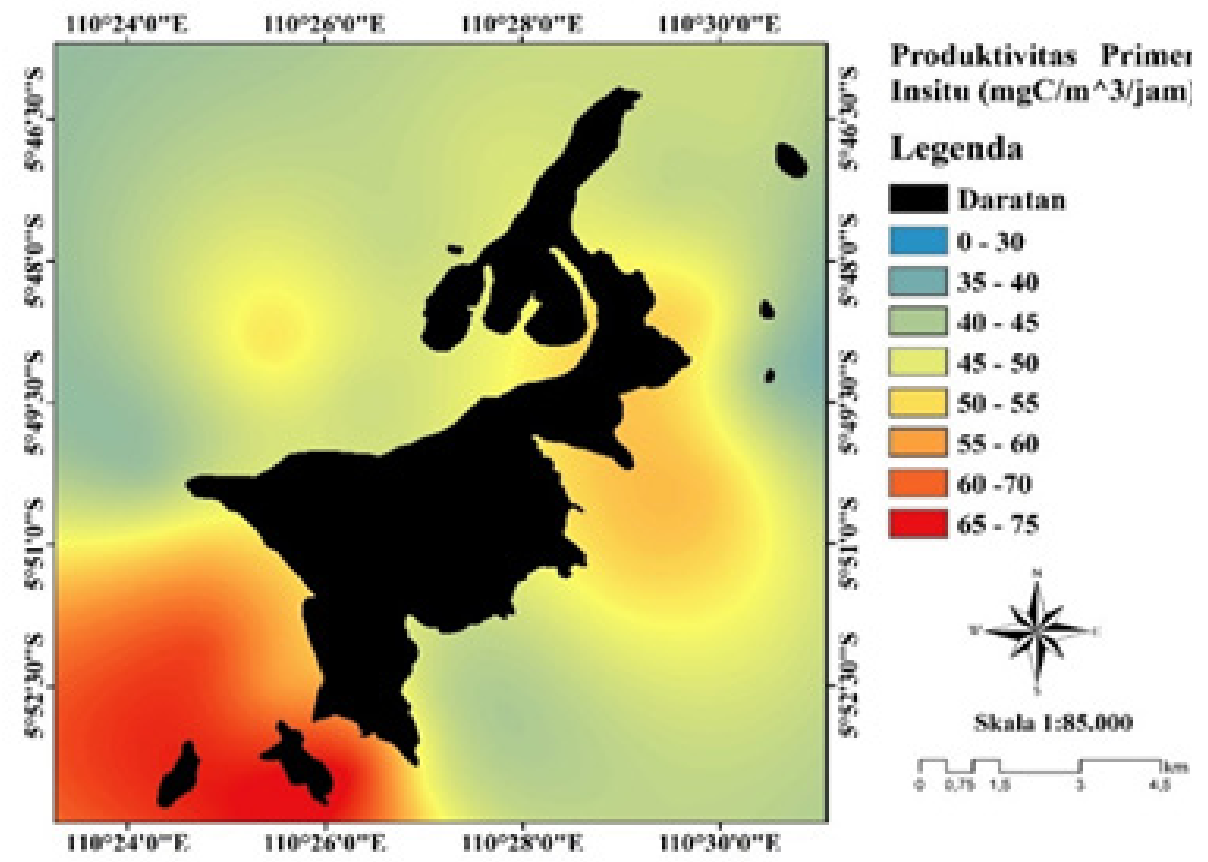

Gambar 7. Peta sebaran spasial produktivitas primer data insitu 


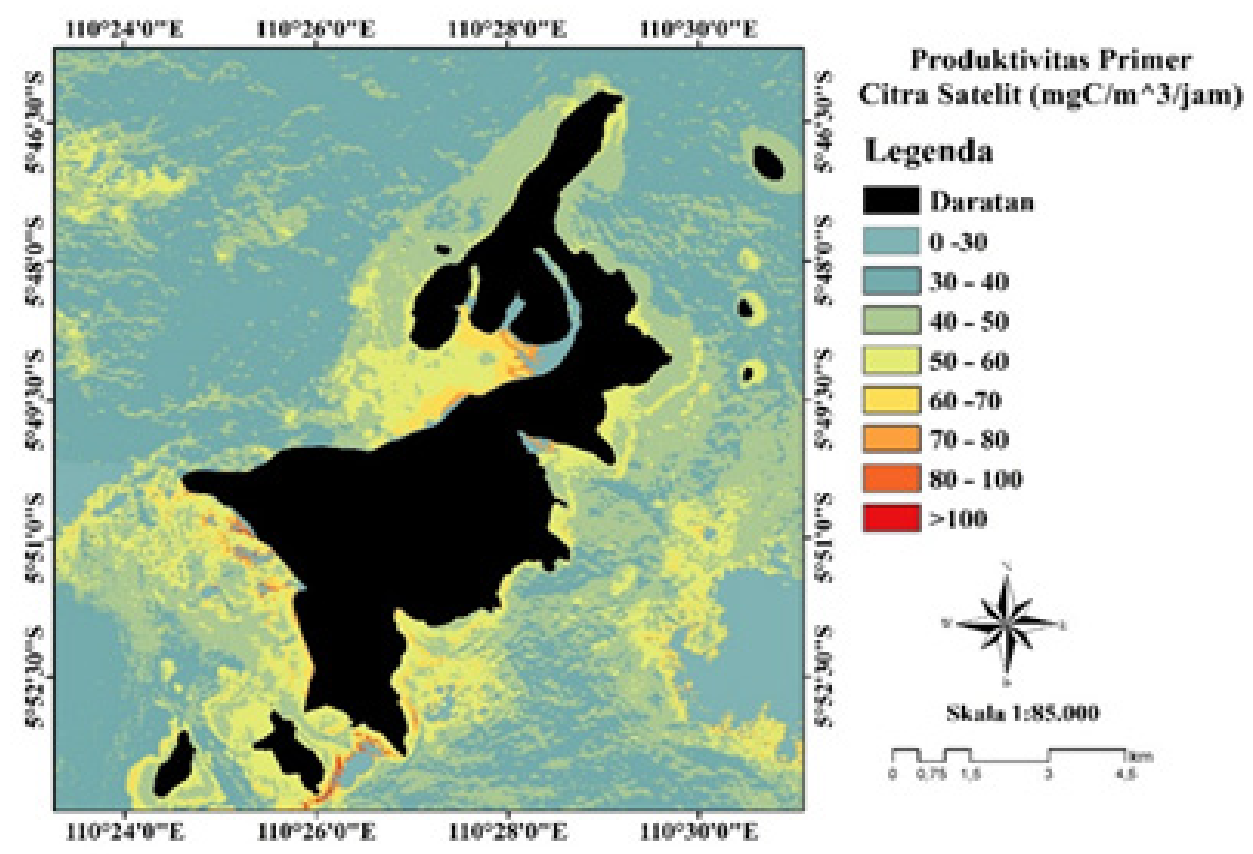

Gambar 8. Peta Sebaran spasial produktivitas primer citra satelit

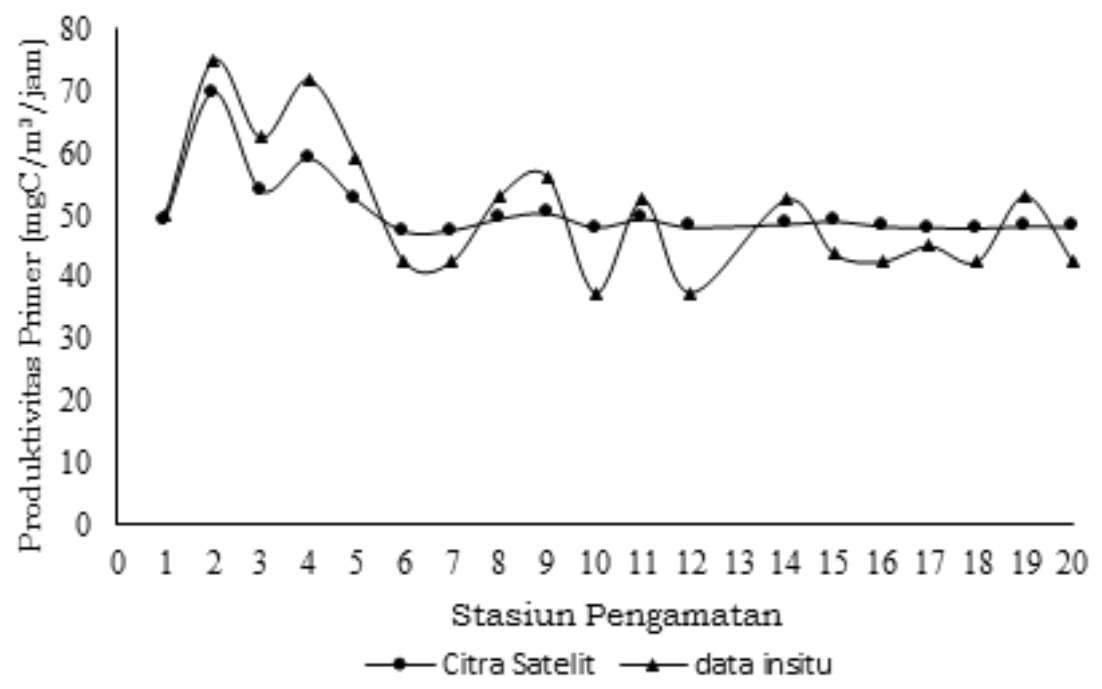

Gambar 9. Grafik nilai produktivitas primer pengukuran insitu dan satelit

\section{KESIMPULAN DAN SARAN}

\section{Kesimpulan}

Kesimpulan yang diperoleh dari penelitian ini adalah hubungan antara konsentrasi klorofil-a permukaan dan konsentrasi klorofil-a seluruh daerah eufotik digunakan untuk mencari nilai konsentrasi klorofil-a secara keseluruhan di kolom perairan dengan koefisien korelasi sebesar 0.75. Estimasi produktivitas primer dapat diduga berdasarkan nilai konsentrasi klorofil-a kolom air seluruh daerah eufotik yang menghasilkan persamaan linier $\mathrm{PP}=$
22.746+95.536Keu dengan $(\mathrm{R} 2)=0.66$. Berdasarkan persamaan tersebut dapat dilakukan analisis spasial citra satelit untuk mengestimasi produktivitas primer di suatu wilayah.

\section{Saran}

Saran untuk penelitian selanjutnya adalah perlu dikaji lebih lanjut mengenai model biooptik laut untuk membuat model produktivitas primer sehingga dapat digunakan secara lebih akurat untuk analisis citra satelit. 


\section{DAFTAR PUSTAKA}

[APHA] American Public Health Association. 2012. Standard Methods for the Examination of Water and Waste Water. 22st ed. Washington (US): APHA.

Asriyana, Yuliana. 2012. Produktivitas Perairan. Bumi Aksara. Jakarta.

Behrenfeld MJ, Falkowski, PG. 1997. Photosynthetic rates derived from satellite-based chlorophyll concentration. Journal of Limnology and Oceanography. 42: 1-20.

Behrenfald MJ, Boss E, Siegel DA, Shea DM. 2005. Carbon-based ocean productivity and phytoplankton physiology from space. Global Biogeochemical Cycles. Vol 19.

Campbell J, Antonie D, Armstrong R, Arrigo $\mathrm{K}$, Balch W, Barber R, Behrenfeld M, Bidigare R, Bishop J, Carr ME, Esaias W, Falkowski P, Hoepffner N, Iverson R, Kiefer D, Lohrenz S, Marra J, Morel A, Ryan J, Vedernikov V, Waters K, Yentsch C, Yoder J. 2002. Comparison of algoritm for estimating ocean primary production from surface chlorophyll, temperature and irradiance. Global biogeochemical cycles. Vol 16. No 3, 1035.

Hill VJ, Zimmerman, RC. 2010. Estimates of primary production by remote sensing in the Arctic Ocean: assessment of accuracy with passive and active sensors. Deep Sea Research I, 57: 1243-1254.

Hirawake T, Shinmyo K, Fujiwara A, Saitoh S. 2012. Satellite remote sensing of primary productivity in Bering and Chuchi seas using an absorption based approach. Journal Marine Science. 69(7): 1194-1204.

Kirk JTO. 2011. Light and Photosynthesis in Aquatic Ecosystems. Third Edition. Cambridge University press. New York.

Lee ZP, Marra J, Perry MJ, Kahru M. 2014. Estimating oceanic primary productivity from ocean color remote sensing. Journal of Marine Systems 149: 50-59.

Ma S, Tao Z, Yang X, Member, IEEE, Yu Y, Zhou X, Ma W, Li Z. 2014. Estimation of marine primary productivity from sattelite-derived phytoplankton absorption data. IEEE Journal of Selected Topics in Apllied Earth Observation and Remote Sensing, Vol 7. No7.

Moses WJ, Gitelson AA, Berdnikov S,
Povazhnyy V. 2009. Satellite estimation of chlorophyll-a concentration using the red and nir bands of Meris - the Azov sea case study. IEEE Geoscience and Remote Sensing Letter. Vol. 6, No.4.

Nontji A. 1984. Biomassa dan produktivitas fitoplankton di perairan teluk Jakarta serta kaitannya dengan faktor-faktor lingkungan. [Disertasi] Bogor: Institut Pertanian Bogor.

Parson TR, Takahashi M. Hargrave B. 1984. Biological Oceanographic Processes. Pergamon Press. New York.

Pentury R. 1997. Algoritma pendugaan konsentrasi klorofil-a di perairan teluk Ambon dengan menggunakan citra Landsat-ETM. [Tesis]. Bogor: Institut Pertanian Bogor.

Siswanto E, Ishizaka J, Yokouchi K. 2005. Estimating chlorophyll-a vertical profiles from satellite data and the implication for primary productivity in the kuroshio front of the east china sea. Journal of Oceanoghraphy. Vol 61pp. 575-589.

Supriharyono. 2009. Konservasi Ekosistem Sumberdaya Hayati di Wilayah Pesisir dan Laut Tropis. Pustaka Pelajar. Yogyakarta.

Susilo SB, Adkha I, Damar A. 1995. Penggunaan data citra landsat hasil olahan digital untuk pendugaan sebaran horizontal produktivitas primer di perairan kabupaten Subang, Jawa Barat. Jurnal Ilmu-Ilmu Perairan dan Perikanan Indonesia. 3(1): 57 - 63.

Susilo SB. 1999. Konsentrasi klorofil-a sebagai penduga produktivitas primer perairan. Jurnal Ilmu-Ilmu Perairan dan Perikanan Indonesia. 6(2): 73-82

Tambaru R. 2000. Pengaruh waktu inkubasi terhadap produktivitas primer di perairan Teluk Hurun. [Tesis] Bogor: Institut Pertanian Bogor.

Tambaru R. 2008. Dinamika Komunitas fitoplankton dalam kaitannya dengan produktivitas perairan di perairan pesisir Maros Sulawesi Selatan. [Disertasi] Bogor: Institut Pertanian Bogor.

[USGS] United State Geological Survey. 2015. Landsat 8 Data Users Handbook. Department of interior. U.S. Geological Survey. LSDS-1574 Version 1.0.

Zhang C, Han M. 2015. Mapping chlorophyll-a concentration in Laizhou Bay using Landsat 8 OLI data. Proceedings of the 36th IAHR World Congress. Netherland 